Abstracta Iranica Abstracta Iranica

Revue bibliographique pour le domaine irano-aryen

Volume 27 | 2006

Comptes rendus des publications de 2004

\title{
" Again on the chronology of the Tall-e Takht at Pasargades ». Parthica, vol. 6, (2004), pp. 95-100, 3 fig.
}

\section{Rémy Boucharlat}

\section{(2) OpenEdition}

Journals

Édition électronique

URL : http://journals.openedition.org/abstractairanica/5800

DOI : 10.4000/abstractairanica.5800

ISSN : 1961-960X

Éditeur :

CNRS (UMR 7528 Mondes iraniens et indiens), Éditions de l'IFRI

\section{Édition imprimée}

Date de publication : 15 mai 2006

ISSN : 0240-8910

Référence électronique

Rémy Boucharlat, « "Again on the chronology of the Tall-e Takht at Pasargades ». Parthica, vol. 6,

(2004), pp. 95-100, 3 fig. », Abstracta Iranica [En ligne], Volume 27 | 2006, document 115, mis en ligne le 02 janvier 2007, consulté le 25 septembre 2020. URL : http://journals.openedition.org/ abstractairanica/5800 ; DOI : https://doi.org/10.4000/abstractairanica.5800

Ce document a été généré automatiquement le 25 septembre 2020.

Tous droits réservés 


\title{
« Again on the chronology of the Tall-e Takht at Pasargades ». Parthica, vol. 6, (2004), pp. 95-100, 3 fig.
}

\author{
Rémy Boucharlat
}

Avec une méthodologie claire et convaincante, P.C. revient sur la question de la date disputée des niveaux post-achéménides de Pasargades, à partir d'un objet unique sur la plateforme Tall-i Takht de Pasargades. Il s'agit d'un couvercle de schiste vert décoré de rosettes. Il provient de la période II qui se termine dans un incendie survenu selon le fouilleur D. Stronach vers 280 av. J.-C. - datation établie sur la base de deux trésors monétaires séleucides, trouvés dans un contexte stratigraphique peu sûr pour l'un d'eux. En 1993, M. Taddei, relevant que la chronologie reposait uniquement sur les données numismatiques et que, selon Stronach lui-même, certaines catégories d'objets pouvaient avoir été produits jusqu'au $2^{\mathrm{e}}-1^{\mathrm{er}} \mathrm{s}$., proposait d'abaisser la date du niveau II d'un siècle au moins, insistant sur les similitudes du couvercle, matériau et décor, avec les productions du Gandhara. Récemment, D. Potts, préférant une origine occidentale, hellénistique, de l'objet ne voyait pas d'objection à revenir à la date proposée par Stronach. Ici, P.C. relève un argument $a$ silentio des tenants de la chronologie haute : la perte de contrôle du Fars par les Séleucides et l'apparition du monnayage des Fratarakas ont été datées, depuis Herzfeld, du début du $3^{\mathrm{e}} \mathrm{s}$. Or, depuis les travaux de M. Alram et de J. Wiesehöfer, on sait qu'il faut rajeunir cette évolution d'un siècle environ, et en conséquence, suggère P.C., la fin de la Période II de Pasargades. 
INDEX

Thèmes : 3.2.2. Pré-Achéménides et Achéménides

\section{AUTEURS}

RÉMY BOUCHARLAT

IFRI-CNRS - Téhéran-Lyon 